\title{
COMPARATIVE STUDY ON THE EFFICIENCY OF SOME COMMON COMPOUNDS USED IN CONTROLLING DENTAL HYPERSENSITIVITY IN NONCARIOUS CERVICAL INJURIES
}

\author{
MĂDĂLINA VIOLETA PERIEANU ${ }^{1}$, CLAUDIA-CAMELIA BURCEA ${ }^{2}$, \\ VIOREL ȘTEFAN PERIEANU ${ }^{3}$, MIHAI BURLIBAȘA ${ }^{4}$, GABRIELA TĂNASE ${ }^{5}$, \\ CAMELIA IONESCU ${ }^{6}$, IULIANA BABIUC ${ }^{7}$, CORINA MARILENA CRISTACHE ${ }^{8}$, \\ RADU COSTEA ${ }^{9}$, IRINA DONCIU ${ }^{10}$, LUMINIŢA OANCEA ${ }^{11}$, ILEANA IONESCU ${ }^{12}$, \\ ELENA-CRISTINA MARCOV ${ }^{13}$, MĂDĂLINA MALIȚA ${ }^{14}$, IRINA ADRIANA BEURAN ${ }^{15}$ \\ 1,2,3,4,5,6,7,8,9,10,11,12,13,14,15 “Carol Davila” University of Medicine of Pharmacy Bucharest
}

Keywords: Recaldent ${ }^{\mathrm{TM}}$, potassium nitrate, CPP$A C P$

\begin{abstract}
In general, the treatment of dentin hyperesthesia can be performed either at home or in the dentist's office. The therapeutic approach aims at the use of products, which decrease the excitability of pulp nociceptors or reduce the permeability of the dentin canals. The purpose of this study is to compare the efficiency in the treatment of dentin hyperesthesia of a product containing potassium nitrate, compared to another product using Recaldent ${ }^{\mathrm{TM}}$ Technology. The results of this study indicated a significant decrease in pain sensitivity both after application of the product using Recaldent ${ }^{\mathrm{TM}}$ Technology and after the product containing potassium nitrate, the results being slightly in favour of the first product.
\end{abstract}

\section{INTRODUCTION}

As it is well known, dentin hyperesthesia is a common condition in adults of all ages. Thus, there are studies that state that the highest incidence of dentin hyperesthesia is found in patients aged 30-39 years.

Specifically, dentin hyperesthesia correlates with exposure of dentin tubules due to acid erosion, acidogenic diet, aggressive brushing techniques, brushing with highly abrasive whitening pastes, periodontal disease accompanied by gingival retraction and/ or consequent periodontal surgery.(1,2) The most affected teeth are the lower molars and premolars, on the buccal surfaces, which are the least protected from saliva. The trigger for toothache is contact with cold or acidic foods and/or beverages, toothbrushes or toothpicks. Once the dentin tubules are opened, the movement of the dentin lymph triggers nociceptor reactions associated with odontoblasts.

In general, the treatment of dentin hyperesthesia can be performed either at home or in the dentist's office. The therapeutic approach aims at the use of products, which decrease the excitability of pulp nociceptors or reduce the permeability of the dentin canals.( 3 )

Toothpastes or topical gels that contain $\mathrm{K}$ nitrate and release $\mathrm{K}$ ions increase the excitability threshold of nociceptive receptors and decrease tooth pain. It is recommended to apply these products for a long time in order to maintain the effect.(46)

A second strategy that can be used by patients at home is related to the use of pastes or creams, which obstruct the dentin canals, reducing the flow of dentin lymph. Thus, in some toothpastes there is zirconium silicate, a chemical compound that partially blocks the tubules.

Remineralizing agents stimulate the deposition of mineral aggregates at the open end towards the buccal environment of the canals. Fluoride gels $(\mathrm{NaF}, \mathrm{SnF}, \mathrm{StF})$ form mineral precipitates.(7) Pastes with arginine, calcium carbonate and fluoride seals the dentinal tubules, forming an intracanalicular plug resistant to acid attacks.(8)

1. Recaldent $^{\mathrm{TM}}$ technology $(\mathrm{CPP}-\mathrm{ACP}=$ caseophosphopeptide - amorphous calcium phosphate) is also a very effective method of treating dentin hyperesthesia. In practice, the peptides bind to the dentin surface and initiate the deposition of mineral aggregates in the dentinal tubules, thus decreasing the permeability of the dentin.(9-11)

CPP-ACP technology (caseophosphopeptide amorphous calcium phosphate) is the most effective in increasing calcium levels in dental microbial plaque and oral fluid, enhancing remineralization. Fluoride, distributed simultaneously with the CPP-ACP complex, acts on bacteria in dental plaque and contributes to remineralization.

2.

$$
\text { CPP-ACFP }
$$

nanocomplexes (caseophosphopeptide - amorphous calcium phosphate fluoride)

The synergistic action of CPP-ACP and fluoride has been shown to be beneficial. A toothpaste containing both types of substances, produces a higher degree of remineralization than that obtained, following the singular action of the components.(11) It is known that caseinphosphopeptide (CPP) can stabilize increased concentrations of calcium, phosphate and fluoride ions at $\mathrm{pH}$ values between 4.5 and 7.0. At $\mathrm{pH}<5.5$, CPP-ACFP produces a higher remineralization than the CPPACP complex and the predominantly mineral formed is fluoroapatite, which is much more resistant to acid attack.

Most studies have focused on enamel remineralization, but there has been an increased interest in

\footnotetext{
${ }^{4}$ Corresponding author: Mihai Burlibaşa, Str. Plevnei, Nr. 19 Sector 1, Bucureşti, România, E-mail: mburlibasa@gmail.com, Phone: +40723 472632
} Article received on 20.06.2019 and accepted for publication on 10.08.2020 


\section{CLINICAL ASPECTS}

observing what happens to dentin when substances with remineralizing potential are applied. Dentin has a complex chemical structure with phosphoproteins and a lot of water, which makes it a difficult substrate to approach, especially in in vitro studies, where saliva is missing with its constituents and roles.(12) Recent studies have shown that at the dentin level fluoroapatite is formed predominantly and not calcium fluoride, following the application of neutral sodium fluoride gels, immediately followed by laser treatment - a process called photonic conversion.(13-15) Also, the CPP-ACP complex can stop the evolution of incipient root caries and strengthen the hard dental tissues, illustrating once again the benefits of this type of remineralizing substance.(16-26)

\section{AIM}

The purpose of this study is to compare the efficiency in the treatment of dentin hyperesthesia of a product containing potassium nitrate and which we will call P1 (Product 1), compared to another product, in fact it is a cream that is applied to the teeth at home and using Recaldent ${ }^{\mathrm{TM}}$ Technology (CPP ACP) and which we will call P2 (Product 2).

\section{MATERIALS AND METHODS}

The study was performed on a number of 30 patients, divided into 2 equal groups (figure no. 1):

- G1 - 15 patients, of which 10 women and 5 men, used the product $\mathrm{P} 1$, based on silver nitrate;

- G2 - 15 patients, including 7 women and 8 men, used the product P2, based on Recaldent ${ }^{\mathrm{TM}}$ Technology (CPP $\mathrm{ACP})$.

Figure no. 1. Gender distribution of the subjects from the 2 groups involved in the study

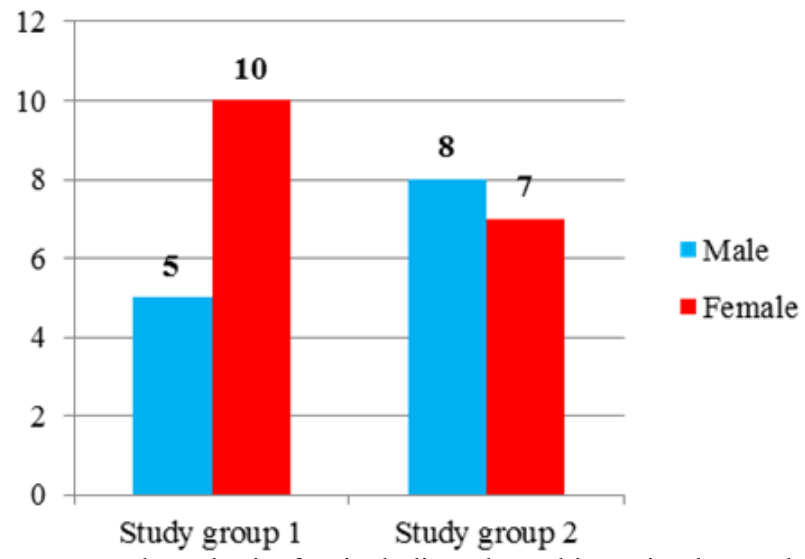

The criteria for including the subjects in the study were the following:

- The patient must have at least 1 sensitive tooth (with dentin hyperesthesia);

Presence of erosion, abrasion or gingival retraction;

- To be sensitive to contact with cold, hot, sweet or sour.

The criteria for excluding the subjects from the study were:

Suspicion of pulpitis;

Allergy to any of the ingredients of the products used;

Teeth with cracks, with carious lesions;

Teeth with extensive coronary restorations;

Endodontically treated teeth;

Patients who have undergone periodontal surgery in the last three months before the start of treatment for hyperesthesia;

Teeth with crowns or abutment teeth;

Patients with physical or mental disabilities;
Immunosuppressed patients;

Pregnant or lactating patients;

Patients following specific diets;

Patients who have previously used such products for sensitization.

Product P1. It has as active ingredient potassium nitrate (up to $5 \%$ ) and $\mathrm{NaF}$ (up to $0.31 \%$ - about $1400 \mathrm{ppm}$ ). Other ingredients contained in this product are: sorbitol, glycerol, silicon, purified water, sodium lauryl sulfate, titanium oxide (E171), sodium saccharin, mint flavor, cocamidopropyl betaine, xanthan gum and macrogol.

Product P2. It is a cream that contains the ACP-CPP complex and is a supplier of calcium and phosphate ions. The paste relieves painful sensitivity in about 3-5 minutes. Action mechanism: The cream releases the ACP-CPP complex that adheres to soft parts, dental microbial plaque and hydroxyapatite, releasing amorphous calcium and phosphate ions into saliva and dental microbial plaque. These ions have the ability to stimulate remineralization and to reduce acidity in the oral environment. Applied on the tooth surface, this compound interacts with hydrogen ions and forms calcium hydrogen phosphate which, depending on the concentration gradient, enters the tooth and reacts with water, thus removing mineral defects. On exposed surfaces of dentin to the oral environment, the protein component of the $\mathrm{P} 2$ product chemically binds to the tooth and forms intracanalicular plugs, which clog the dentinal tubules. There are studies that attest to the long-term positive effect of using these products.

\section{Working protocol}

All patients involved in the study were informed verbally and in writing about the purpose of the study and were explained the treatment procedure. They signed an informed consent. Patients were instructed to use a soft toothbrush and to brush twice a day with the P1 product, which was handed to them, insisting on sensitive areas. Patients in group 2, with the $\mathrm{P} 2$ product using Recaldent ${ }^{\mathrm{TM}} \mathrm{Technology}$, were also instructed on how to apply the creams to the cervical areas: an amount of cream the size of a pea is applied on the finger and then the sensitive areas, and not only, are massaged. It is recommended to apply on all teeth, in the evening after tooth brushing. As much as possible, the cream should be kept in the oral cavity for about 2-3 minutes, after which the patient spits the excess or can swallow it, because it has no negative effects.

Patients were asked to hand over the containers with $\mathrm{P} 1$ and $\mathrm{P} 2$ products at the control performed by the dental team at 4 weeks.

Sensitivity assessment was performed on the air jet from the dental unit $\left(20-23^{\circ} \mathrm{C}, 40-65 \mathrm{psi}\right)$, applied from $1 \mathrm{~cm}$ away from the affected tooth, followed by the thermal stimulus, more precisely, cold water at a temperature of $4^{\circ} \mathrm{C}$, about 5 minutes after applying the air jet.

The evaluation of the response was done by the patient, on a Visual Analogue Scale (VAS). This scale actually means a $10 \mathrm{~cm}$ line, with $0=$ no pain at the ends and $10=$ unbearable pain. Each patient was asked to mark a line on the scale to indicate the intensity of pain felt when applying the stimulus.

The score was calculated at time 0 , then at intervals of 4 and 6 weeks.

\section{RESULTS}

During the 6 weeks of evaluation, no allergic reaction was observed to either of the ingredients of the two desensitizing agents used in the study. In table no. 1 and in figure no. 2 there are presented the results, regarding the evaluation of the sensitivity to air stimulation, using the Visual Analogue Scale (VAS) 


\section{CLINICAL ASPECTS}

Initially (at time zero) for group 1 (which produced P1), an average VAS score of $7.4 \pm 2.5$ was recorded. For group 2 , the initial VAS score was $5.4 \pm 2.1$. After the use of desensitizers, there was a significant decrease in the VAS score in both groups. After 4 weeks reaching 4.1 (Group 1) and 2.8 (Group 2) and after 6 weeks at 2.1 (those with product P1) and 1.5 in the group that used product $\mathrm{P} 2$. Comparing group 1 with group 2, there were no significant differences in the VAS score in all 3 periods. Both Product P1 and Product P2 have been shown to be effective in the treatment of dentin hyperesthesia.

Following the centralization of the results obtained by analysing the two study groups, the values in table no. 1 were obtained.

Table no. 1. Sensitivity assessment using the Visual Analogue Scale, for the painful air stimulus

\begin{tabular}{|c|c|c|c|c|}
\hline $\begin{array}{l}\text { Time of } \\
\text { examination }\end{array}$ & Group & $\begin{array}{l}\text { Average } \pm \\
\text { Standard } \\
\text { Deviation }\end{array}$ & $\mathrm{t}$ & $\mathbf{p}$ \\
\hline \multirow[b]{2}{*}{ Initial moment } & G1 & $7,4 \pm 2,5$ & \multirow[b]{2}{*}{0,923} & \multirow{2}{*}{$\mathrm{p}=0,358$} \\
\hline & $\mathrm{G} 2$ & $5,4 \pm 2,1$ & & \\
\hline \multirow{2}{*}{ At 4 weeks } & G1 & $4,1 \pm 2,1$ & \multirow{2}{*}{1,604} & \multirow{2}{*}{$\mathrm{p}=0,120$} \\
\hline & $\mathrm{G} 2$ & $2,8 \pm 1,6$ & & \\
\hline \multirow{2}{*}{ At 6 weeks } & G1 & $2,1 \pm 1,4$ & \multirow{2}{*}{1,148} & \multirow{2}{*}{$p=0,248$} \\
\hline & G2 & $1,5 \pm 0,9$ & & \\
\hline
\end{tabular}

When applying the painful stimulus produced by the air jet, it is noticed the improvement of the VAS values in time, following the application of the two products during the study.

Figure no. 2. The evolution of the average value of VAS for the two study groups, at air stimulation

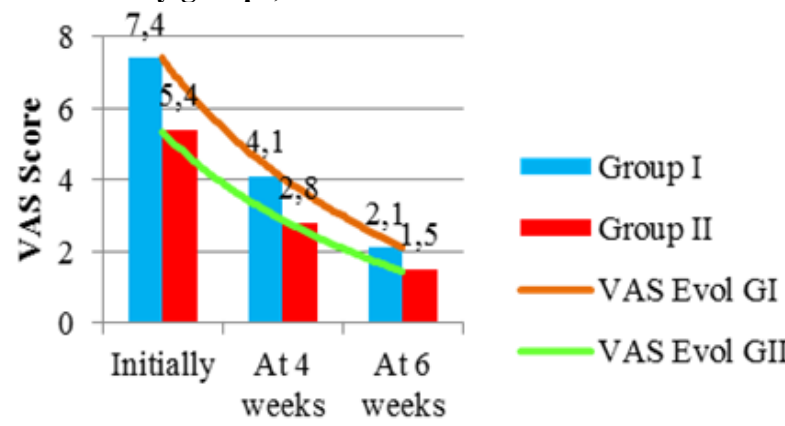

Evaluation time

Table no. 2 and figure no. 3 present the results related to the efficiency of using the two products (P1 and P2), in reducing the painful cold sensation. We started from VAS score values of 8.3 in group 1 and 7.5 in group 2, reaching 5.8 and 4 in 4 weeks. The decrease was significant at 6 weeks when, for users of product $\mathrm{P} 1$, the VAS score reached $3.7 \pm 0.9$, and for product $\mathrm{P} 2$ it reached $3.1 \pm 1.6$.

Table no. 2. Sensitivity evaluation using the Visual Analogue Scale, for the thermal stimulus (cold)

\begin{tabular}{|c|c|c|c|c|}
\hline $\begin{array}{l}\text { Time of } \\
\text { examination }\end{array}$ & Group & $\begin{array}{l}\text { Average } \pm \\
\text { Standard } \\
\text { Deviation }\end{array}$ & $\mathbf{t}$ & $\mathbf{p}$ \\
\hline \multirow{2}{*}{ Initial moment } & G1 & $8,3 \pm 1,9$ & \multirow{2}{*}{1,503} & \multirow{2}{*}{$\mathrm{p}=0,141$} \\
\hline & G2 & $7,5 \pm 2,1$ & & \\
\hline \multirow{2}{*}{ At 4 weeks } & G1 & $5,8 \pm 1,3$ & \multirow{2}{*}{1,562} & \multirow{2}{*}{$\mathrm{p}=0,135$} \\
\hline & G2 & $4,0 \pm 2,2$ & & \\
\hline \multirow{2}{*}{ At 6 weeks } & G1 & $3,7 \pm 0,9$ & \multirow{2}{*}{1,207} & \multirow{2}{*}{$\mathrm{p}=0,229$} \\
\hline & G2 & $3,1 \pm 1,6$ & & \\
\hline
\end{tabular}

By analysing the mean values of VAS following air stimulation, for the first study group, it is noted that, at both 4 and 6 weeks, the values obtained are statistically significant ( $p$ $<0.001$ ), showing a favourable evolution for treatment with product P1 (table no. 3).
Figure no. 3. The evolution of the average value of VAS for the two study groups, at cold stimulation

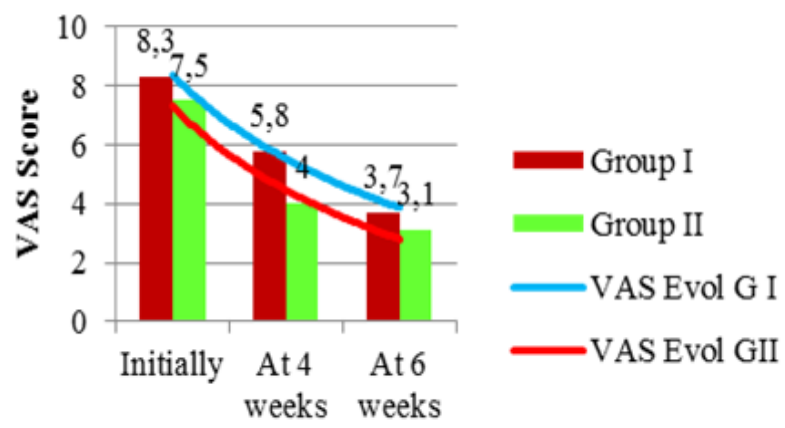

Evaluation time

Table no. 3. Comparison of the average values of the VAS for Group I with the values recorded at the initial time, for air stimulation

\begin{tabular}{|c|l|l|c|c|}
\hline \multirow{4}{*}{$\begin{array}{c}\text { Group I } \\
\text { Air }\end{array}$} & $\begin{array}{l}\text { Evaluation } \\
\text { time }\end{array}$ & $\begin{array}{l}\text { Average } \pm \\
\text { Standard } \\
\text { Deviation }\end{array}$ & F & p \\
\cline { 2 - 3 } stimulation & Initially & $7,4 \pm 2,5$ & \multirow{2}{*}{13,152} & $<0,001$ \\
\cline { 2 - 3 } & At 4 weeks & $4,1 \pm 2,1$ & \\
\cline { 2 - 3 } & At 6 weeks & $2,1 \pm 1,4$ & & \\
\hline
\end{tabular}

For the second Group, the one in which the product P2 was used, the evolution of the VSA values from the initial stage, at 4 weeks and at 6 weeks, shows a statistically significant improvement, confirmed by the $p$ value $<0.001$ (table no. 4).

Table no. 4. Comparison of the average values of the VSA for Group II with the values recorded at the initial time, for air stimulation

\begin{tabular}{|c|l|l|c|c|}
\hline \multirow{4}{*}{$\begin{array}{c}\text { Group II } \\
\text { Air } \\
\text { stimulation }\end{array}$} & $\begin{array}{l}\text { Evaluation } \\
\text { time }\end{array}$ & $\begin{array}{l}\text { Average } \pm \\
\text { Standard } \\
\text { Deviation }\end{array}$ & F & p \\
\cline { 2 - 3 } & Initially & $5,4 \pm 2,1$ & \multirow{2}{*}{15,148} & $<0,001$ \\
\cline { 2 - 3 } & At 4 weeks & $2,8 \pm 1,6$ & \\
\cline { 2 - 3 } & At 6 weeks & $1,5 \pm 0,9$ & \\
\hline
\end{tabular}

For the application of cold painful stimulus, the initial values of VSA were higher than those obtained when applying the painful air stimulus but, by the successive analysis of the three study stages, the favourable effect was noticed, following the application of desensitizing products.

After the use of product P1, the initial values started from $8.3 \pm 1.9$, with a reduction after application for 4 weeks to values with an average of $5.8 \pm 1.3$, and at the end of the treatment, after application for 6 weeks, to obtain values with an average of $3.7 \pm 0.9$ (table no. 5).

Table no. 5. Comparison of mean VSA values for Group I with the values recorded at baseline for cold stimulation

\begin{tabular}{|c|l|l|c|c|}
\hline \multirow{2}{*}{$\begin{array}{c}\text { Group I } \\
\text { Cold } \\
\text { stimulation }\end{array}$} & $\begin{array}{l}\text { Evaluation } \\
\text { time }\end{array}$ & $\begin{array}{l}\text { Average } \pm \\
\text { Standard } \\
\text { Deviation }\end{array}$ & F & p \\
\cline { 2 - 3 } & Initially & $8,3 \pm 1,9$ & \multirow{2}{*}{51,369} & $<0,001$ \\
\cline { 2 - 3 } & At 4 weeks & $5,8 \pm 1,3$ & \multirow{2}{*}{} \\
\cline { 2 - 3 } & At 6 weeks & $3,7 \pm 0,9$ & & \\
\end{tabular}

Following the application of product P2, for Study Group II, the values obtained for VAS started from the initial mean values of $7,5 \pm 2,1$, obtaining at the end average values of approximately $3,1 \pm 1,6$ (table no. 6).

For the comparative analysis of the values obtained for the three stages, the Bonferroni multiple comparison analysis was used, an analysis that shows whether the evolution between 


\section{CLINICAL ASPECTS}

different stages is statistically significant or not.

Table no. 6. Comparison of the mean VAS values for Group II with the values recorded at the baseline, for cold stimulation

\begin{tabular}{|c|l|l|c|c|}
\hline \multirow{4}{*}{$\begin{array}{c}\text { Group II } \\
\text { Cold } \\
\text { Stimulation }\end{array}$} & $\begin{array}{l}\text { Evaluation } \\
\text { time }\end{array}$ & $\begin{array}{l}\text { Average } \pm \\
\text { Standard } \\
\text { Deviation }\end{array}$ & F & p \\
\cline { 2 - 3 } & Initially & $7,5 \pm 2,1$ & \multirow{2}{*}{14,421} & $<0,001$ \\
\cline { 2 - 3 } & At 4 weeks & $4,0 \pm 2,2$ & & \\
\cline { 2 - 5 } & At 6 weeks & $3,1 \pm 1,6$ & & \\
\hline
\end{tabular}

For the first study group, the Bonferroni analysis indicates a statistically significant difference between the Initial Stage and the 6-week Analysis. The other differences, between the Initial Stage and the 4-week Analysis, respectively between the 4-week Analysis and the 6-week Analysis, even if they show an improvement of the VSA values and, implicitly, of the oral health of the patients, are not different enough to have statistical significance (table no. 7).

Table no. 7. Mean difference in VSA values for Group I in response to air stimulation by multiple Bonferroni comparisons for baseline, 4 weeks, and 6 weeks

\begin{tabular}{|c|c|c|c|c|c|}
\hline \multirow{4}{*}{ Group I } & Variable & Time 1 & Time 2 & $\begin{array}{c}\text { Average } \\
\text { difference }\end{array}$ & $\mathbf{p}$ \\
\cline { 2 - 6 } & \multirow{3}{*}{ Air } & Initially & $\begin{array}{c}\text { At 4 } \\
\text { weeks }\end{array}$ & 3.3 & 0.031 \\
\cline { 3 - 6 } & Initially & $\begin{array}{c}\text { At 6 } \\
\text { weeks }\end{array}$ & 5.3 & $<0.001$ \\
\cline { 3 - 6 } & & At 4 weeks & $\begin{array}{c}\text { At 6 } \\
\text { weeks }\end{array}$ & 2 & 0.052 \\
\hline
\end{tabular}

Similar to the results obtained for Group I, in the case of Group II, the statistically significant difference is that between the Initial Stage and the 6-week Analysis (table no. 8).

Table no. 8. The difference in mean VSA values for Group II in response to air stimulation by multiple Bonferroni comparisons for baseline, at 4 weeks and 6 weeks

\begin{tabular}{|c|c|l|c|c|c|}
\hline \multirow{4}{*}{$\begin{array}{c}\text { Group } \\
\text { II }\end{array}$} & Variable & Time 1 & Time 2 & $\begin{array}{c}\text { Average } \\
\text { difference }\end{array}$ & $\mathbf{p}$ \\
\cline { 2 - 6 } & \multirow{2}{*}{ Air } & Initially & $\begin{array}{c}\text { At 4 } \\
\text { weeks }\end{array}$ & 2.6 & 0.002 \\
\cline { 3 - 6 } & & Initially & $\begin{array}{c}\text { At 6 } \\
\text { weeks }\end{array}$ & 3.9 & $<0.001$ \\
\cline { 3 - 6 } & & $\begin{array}{c}\text { At 4 } \\
\text { weeks }\end{array}$ & $\begin{array}{c}\text { At 6 } \\
\text { weeks }\end{array}$ & 1.3 & 0.189 \\
\hline
\end{tabular}

In the case of the application of the cold painful stimulus, for Study Group I, a statistically significant evolution was observed between all three stages of the study. Thus, between the Initial Stage and the 4-week Analysis, between the Initial Stage and the 6-week Analysis, as well as between the 4week Analysis and the 6-week Analysis, the $p$ value for the analysis of multiple Bonferroni comparisons was $<0.001$ (table no. 9).

Table no. 9. The average difference in VSA values for Group $I$ in response to cold stimulation by multiple Bonferroni comparisons for baseline, at 4 weeks and at 6 weeks

\begin{tabular}{|c|c|c|c|c|l|}
\hline \multirow{4}{*}{ Group I } & Variable & Time 1 & Time 2 & $\begin{array}{c}\text { Average } \\
\text { difference }\end{array}$ & $\mathbf{p}$ \\
\cline { 3 - 6 } & \multirow{3}{*}{ Cold } & Initially & $\begin{array}{c}\text { At 4 } \\
\text { weeks }\end{array}$ & 2.5 & $<0.001$ \\
\cline { 3 - 6 } & Initially & $\begin{array}{c}\text { At 6 } \\
\text { weeks }\end{array}$ & 4.6 & $<0.001$ \\
\cline { 3 - 6 } & $\begin{array}{c}\text { At 4 } \\
\text { weeks }\end{array}$ & $\begin{array}{c}\text { At 6 } \\
\text { weeks }\end{array}$ & 2.1 & $<0.001$ \\
\hline
\end{tabular}

For Study Group II, in which the P2 product was used, the statistically significant difference was noticed only between the Initial Stage and the 6-week analysis, for the other differences the $p$ value showed that they are not statistically significant (table no. 10).

Table no. 10. Average difference in VSA values for Group II, in response to cold stimulation by multiple Bonferroni comparisons for baseline, at 4 weeks and 6 weeks

\begin{tabular}{|c|c|c|c|c|c|}
\hline \multirow{4}{*}{$\begin{array}{c}\text { Group } \\
\text { II }\end{array}$} & Variable & Time 1 & Time 2 & $\begin{array}{c}\text { Average } \\
\text { difference }\end{array}$ & $\mathbf{p}$ \\
\cline { 2 - 6 } & \multirow{2}{*}{ Cold } & Initially & $\begin{array}{c}\text { At 4 } \\
\text { weeks }\end{array}$ & 3.5 & 0.021 \\
\cline { 3 - 6 } & & Initially & $\begin{array}{c}\text { At 6 } \\
\text { weeks }\end{array}$ & 4.4 & $<0.001$ \\
\cline { 3 - 6 } & $\begin{array}{c}\text { At 4 } \\
\text { weeks }\end{array}$ & $\begin{array}{c}\text { At 6 } \\
\text { weeks }\end{array}$ & 0.9 & 0.051 \\
\hline
\end{tabular}

\section{DISCUSSIONS}

The results of this study indicated that the use of P2 (uses Recaldent ${ }^{\mathrm{TM}}$ technology) is very effective in the treatment of dentin hyperesthesia, the differences being slightly in the advantage of this cream, compared to P1 (which contains potassium nitrate).

Toothache has multiple causes, so the combination of treatment methods, such as those mentioned in our study, with advising patients on diet, salivary protection etc., thus becomes mandatory. Home treatments are cheaper and easier to use. After stopping the application, the effects persist for about 4 weeks, after which the symptoms may recur.

It is important to know that ingestion of products using Recaldent ${ }^{\mathrm{TM}}$ technology (with CPP-ACP = caseophosphopeptide case - amorphous calcium phosphate) is safe. It does not contain lactose, so patients with intolerance to this substance can use it without any problems. It is not indicated in patients with allergies to milk proteins, benzoates or other components of the cream.

A generally accepted fact is that, over time, the painful sensitivity decreases, even without treatment. The causes appear to be either the natural obstruction of the dentinal canals, or the low number of tubules, or the deposition of repair dentin.(27)

The products that can be applied at home are really comfortable for the patient, but at the same time, they must be applied continuously or regularly, in order to maintain and preserve the result.

Attention must also be paid to the causes that lead to the appearance of dentin hyperesthesia, in order to approach the problems correctly therapeutically, in order to achieve long-term success.

But, in order to obtain even more relevant results, it might be advisable to evaluate the lifestyle, but also the eating habits of each patient, in order to correlate them with the intensity of the painful sensitivity felt.

\section{CONCLUSIONS}

The results of this study indicated a significant decrease in pain sensitivity both after application of the P2 product using Recaldent ${ }^{\mathrm{TM}}$ Technology (produced with CPPACP $=$ caseophosphopeptide - amorphous calcium phosphate) and after the P1 product (containing potassium nitrate), the results being slightly in favour of the product $\mathrm{P} 2$.

At intervals of 4 and 6 weeks, the results showed a significant improvement in patient comfort. It would be advisable to record the patient's eating habits and lifestyle to determine whether there is a link between the application of desensitizing toothpastes and maintaining or not of eating habits.

The results of our study are based on subjective data, because we thought it was the best way to assess the level of pain. We used two stimuli to make the assessment as accurate as possible. 


\section{CLINICAL ASPECTS}

Acknowledgement: In this article, all the authors have equal contributions.

\section{REFERENCES}

1. Bartold PM. Dentinal hypersensitivity: A review. Aust Dent J. 2006;51(3):212-276.

2. Young WG, Khan F. Sites of dental erosion are salivadependent. J Oral Rehabil. 2002;29(1):35-43.

3. Vieira AH, Santiago SL. Management of dentinal hypersensitivity. Gen Dent. 2009;57(2):120-128.

4. Schiff T, Zhang YP, DeVizio W, et al. A randomized clinical trial of the desensitizing efficacy of three dentifrices. Compend Contin Educ Dent Suppl. 2000;(27):4-28.

5. Conforti N, Battista GW, Petrone DM, et al. Comparative investigation of the desensitizing efficacy of a new dentifrice: a 14-day clinical study. Compend Contin Educ Dent Suppl. 2000;(27):17-28.

6. Sowinski J, Ayad F, Petrone M, et al. Comparative investigations of the desensitising efficacy of a new dentifrice. J Clin Periodontol. 2001;28(11):1032-1036.

7. Sensabaugh C, Sagel ME. Stannous fluoride dentifrice with sodium hexametaphosphate: review of laboratory, clinical and practice-based data. J Dent Hyg. 2009;83(2):70-78.

8. Panagakos F, Schiff T, Guignon A. Dentin hypersensitivity: effective treatment with an in-office desensitizing paste containing $8 \%$ arginine and calcium carbonate. Am J Dent. 2009; 22 Spec No A: 3A-7A.

9. Reynolds EC. Treatment for sensitive teeth. United States Patent 5, 981, 475. 1999

10. Gandolfi MG, Silvia F, H PD, Gasparotto G, Carlo P. Calcium silicate coating derived from Portland cement as treatment for hypersensitive dentine. $\mathrm{J}$ Dent. 2008;36(8):565-578.

11. Reynolds EC, Cai F, Cochrane NJ et al. Fluoride and casein phosphopeptide-amorphous calcium phosphate. J Dent Res. 2008;87(4):344-348.

12. Habelitz S, Marshall SJ, Marshall GW Jr, Balooch M. Mechanical properties of human dental enamel on the nanometre scale. Arch Oral Biol. 2001;46(2):173-183.

13. Vlacic J, Meyers IA, Walsh LJ. Laser-activated fluoride treatment of enamel as prevention against erosion. Aust Dent J. 2007;52(3):175-180.

14. Vlacic J, Meyers IA, Kim J, Walsh LJ. Laser-activated fluoride treatment of enamel against an artificial caries challenge: comparison of five wavelengths. Aust Dent J. 2007;52(2):101-105

15. Vlacic J, Meyers IA, Walsh L. Photonic conversion of hydroxyapapite to fluorapatite: A possible mechanism for laser-activated fluoride therapy. J Oral Laser Appl. 2008;8(2):95-102.

16. Burlibașa L, Zărnescu O, Cucu N, Gavrilă L. Chromatin dynamics in Triturus cristatus oogenesis: An epigenetic approach. Zygote. November 2008;16(4):315-326.

17. Popescu FD, Popescu SM, Burlibașa M. Platinum group metals as contact allergens in oral rehabilitation. Metalurgia International. 2010; 15: 12-18.

18. Mihai A, Chifiriuc CM, Lazăr V, Stănescu R, Burlibașa M, Ispas DC. Microbial biofilms in dental medicine in reference to implanto-prostethic rehabilitation. Rev Chir Oro-MaxiloFac Implantol. 2008;1(1):9-13.

19. Ionescu CA, Popovici LR, Mocuța D, Malița C, Burlibașa M. The quality of human life from the perspective of sustainable development Metalurgia International. 2009;14:41-43.

20. Mocuța D, Popovici IA, Burlibașa L, Cristache G, Sfeatcu $\mathrm{R}$, Bodnar $\mathrm{T}$. Impact of the living conditions on population health. Metalurgia International. 2009;14:17-19.
21. Burlibașa M, Muntianu L, Tănase G, Bucur MB, Comes CA, Ionescu CA. Study on microbial contamination of biomaterials in medical practice. Metalurgia International. 2010; Vol. XV, Spec. Issue No. 2, p. 163-166.

22. Ispas DC, Efetene OA, Burlibaşa M, Bucur MB, Tănase G, Cristache CM. Implications of titanium in orthodontics and dental facial orthopedics. Metalurgia International. 2011; Vol. XVI, Isuue No. 10, p. 72-74.

23. Tănase G, Burlibașa M, Muntianu L, Simion I, Bucur MB, Ionescu CA. Testing the antibacterial potential of biomaterials in medical practice. Metalurgia International. 2010; Vol. XV, Spec. Issue No. 2, p. 160-162.

24. Burlibașa M, Tănase G, Muntianu L, Murgu AI, Teodorescu E, Malița C. Quality of life, a multidisciplinary concept with economic and social impacts in medical practice. Metalurgia International. 2010; Vol. XV, Spec. Issue No. 4, p. 88-90.

25. Burlibaşa M, Cernușcă-Mițariu M, Burcea CC, Mițariu M, Ferechide D. Halogen compounds - theoretical, physiological and practical aspects regarding the decontamination, disinfection and sterilisation of intsruments and biomaterials in dental medicine practice. Metalurgia International. 2012; Vol. XVIII, Spec. Issue No. 3, p. 54-57.

26. Burlibașa M, Cernușcă-Mițariu M, Cernușcă-Mițariu S, Mițariu M, Malița M. Theoretical and practical aspects related to biomaterials decontamination in dental medicine (with reference to dental prosthetics). Metalurgia International. 2013; Vol. XVIII, No. 4, p. 261-267.

27. Bissada NF. Symptomatology and clinical features of hypersensitive teeth. Arch Oral Biol. 1994; Vol. 39(Suppl), p. S31-S32. 